\title{
Coastal Reef and Seagrass Monitoring for Coastal Ecosystem Management
}

\author{
Wahyu Lazuardi ${ }^{1,4}$, Ridwan Ardiyanto ${ }^{1}$, Muh Aris Marfai ${ }^{2,4 *}$, Bachtiar Wahyu Mutaqin ${ }^{2}$, Denny Wijaya Kusuma ${ }^{3}$ \\ ${ }^{1}$ Magister Program on Geography in the Area of Coastal Area and Watershed Planning and Management, Faculty Geography, \\ Universitas Gadjah Mada, Yogyakarta 55281, Indonesia \\ ${ }^{2}$ Coastal and Watershed Research Group, Faculty of Geography, Universitas Gadjah Mada, Yogyakarta 55281, Indonesia \\ ${ }^{3}$ Institute for Marine Research and Observation, Ministry of Marine Affairs and Fisheries of Republic of Indonesia, Jembrana \\ 82251 , Indonesia \\ ${ }^{4}$ Geospatial Information Agency, Bogor 16911, Indonesia
}

Corresponding Author Email: arismarfai@ugm.ac.id

https://doi.org/10.18280/ijsdp.160317

Received: 22 December 2020

Accepted: 26 May 2021

\section{Keywords:}

seagrass, coral reefs, sentinel-2A MSI, machine learning, Indonesia

\begin{abstract}
The growth of human occupations in coastal areas and climate change impact have changed the dynamics of seagrass cover and accelerated the damage to coral reefs globally. For these reasons, coastal management measures need to be developed and renewed to preserve the state of seagrass beds and coral reefs. An example includes the improvement of spatial and multitemporal analyses. This study sought to analyze changes in seagrass cover and damages to coral reefs in Gili Sumber Kima, Buleleng Regency, Bali based on multitemporal Sentinel 2A-MSI imagery. The algorithms of a machine learning, Random Forest (RF), and a Support Vector Machine (SVM) were used to classify the benthic habitats (seagrass beds and coral reefs). Also, a change detection analysis was performed to identify the pattern and the extent to which seagrass beds had changed. The multispectral classification of, particularly, coral reefs was used to explain the condition of this benthic habitat. The results showed $+-70 \%$ to $+-83 \%$ accuracies of estimated seagrass cover, and the change detection analysis revealed three directions of change, namely an increase of 27.9 ha, a decrease by 86 ha, and a preserved state in 157 ha of seagrass cover. The product of coral reefs mapping had an accuracy of $42 \%$, and the coral reefs in Gili Sumber Kima were split almost equally between the good (1505 ha) and damaged ones (1397 ha). With the spatial information on seagrass beds and coral reefs in every region, the ecological functions of the coast can be assessed more straightforwardly and appropriately incorporated as the basis for monitoring the dynamics of resources and coastal area management.
\end{abstract}

\section{INTRODUCTION}

In Indonesia, specific data on seagrass beds and coral reefs are fundamental in carrying out coastal ecosystem management. Seagrass beds and coral reefs are natural resources that provide enormous ecological benefits and contribute substantially to the sustainability of fishery resources in the country. These ecosystems actively produce nutrients for fish, entrap sediments, dissipate current and wave energy, recycle nutrients, and create a highly suitable habitat for shallow marine organisms $[1,2]$. Similar to mangroves, they are known to absorb carbon dioxide $\left(\mathrm{CO}_{2}\right)$. According to the Indonesian Institute of Sciences, seagrass beds in Indonesia $(293,464$ ha) can sequester up to 1.9 to 5.8 megatons of $\mathrm{CO}_{2}$ per year [3]. Also, coral reefs have a very promising yield of fishery products $[4,5]$.

Persistently growing human activities in coastal areas and the effects of climate change have led to the increased dynamics of seagrass cover. For instance, in Indonesia, these dynamics are indicated by changes in the seagrass cover conditions, from $46 \%$ coverage in 2015 to $37.58 \%$ in 2016 , which continued to decrease until 2019 [6]. The Decree of the Indonesian Minister of Environment No. 200 of 2004 differentiates seagrass conditions into three categories based on percent cover of seagrasses in the region, namely healthy (with coverage above 60\%), less healthy (30-59\%), and unhealthy $(<30 \%)$ [7]. Another decree issued by the same Minister, that is, No. 4 of 2001, divides the conditions of coral reefs into two classes, namely damaged (with coverage of 0 $49 \%)$ and healthy $(50-100 \%)$ [8]. The latest record shows that the seagrasses in the country cover $37.58 \%$ [3] and, therefore, fall into the category of unhealthy. Meanwhile, the percent cover of coral reefs is around $67 \%$ [6], signifying a healthy condition. Nevertheless, these states do not rule out the possibility of an annual decline. As confirmed by Waycott et al. [2] and Zhang [9], such changes do not only occur in Indonesia, but up to $29 \%$ of the seagrass bed and coral reef ecosystems worldwide have disappeared.

Seagrass bed and coral reef ecosystems need to continue to offer ecological, economic, and educational benefits for the community. Therefore, developing and updating coastal management measures are imperative as an attempt to preserve the conditions of these ecosystems. An example of an effective and efficient management tool is spatial analysis and multitemporal monitoring, which can be justified scientifically and used as a basis for managing seagrass bed and coral reef 
ecosystems sustainably. Both spatial analysis and multitemporal monitoring can utilize remote sensing technology to provide data for identifying and analyzing the dynamics of seagrass cover and the condition of coral reefs in specific locations. Remote sensing data can be used for spatial analysis at various scales and periodically, so it greatly facilitates multitemporal coastal monitoring. Remote sensing enables straightforward estimates and analyses of coastal marine ecosystems that change periodically. Also, it assists in the identification and evaluation of seagrass bed and coral reef ecosystem management that can contribute to the growth and preservation of coastal marine environments.

To be more efficient, this data is formed as a mapping model by utilizing the development of digital automation in the form of machine learning algorithms that are able to maximize the results of spatial analysis. This research adapts remote sensing technology for spatial and multitemporal analysis and machine learning algorithms. Especially as an initial stage to meet the information needs of coastal resources, especially coral reefs and seagrass beds, which can then be used for further analysis. This leads to the possibility of developing more universal mapping algorithm using satellite image for rapid mapping and monitoring of coral reef and seagrass [10]. Therefore, this research is expected to be used as a reference in similar studies, especially by government and stakeholders, when applying remote sensing data for coastal monitoring for coastal resources information for management purposes.

Because of its high effectiveness and efficiency, remote sensing has been widely used in coastal resource analysis [1113]. Besides, with multitemporal remote sensing applications, patterns of changes over a particular range of years can be identified [14]. Remote sensing data have been used in several studies of seagrass bed and coral reef cover analysis and confirmed to produce excellent results [15-17]. Some examples of previous research [18] are mapped the biophysical characteristics of seagrass in the form of species, percent cover, and biomass in Moreton Bay using a variety of multispectral and airborne hyperspectral imagery. Lyons et al. [13] mapped percent of seagrass cover multi-temporal in Eastern Banks, Moreton Bay, Australia using OBIA. Roelfsema et al. [19] conducted a coral hierarchical mapping of coral reefs with different information scales. The hierarchy consists of reef, reef type, geomorphic zone and benthic community using object-based classification (OBIA) using IKONOS (4 m) and Quickbird (2.4 m) imagery. Roelfsema et al. [20] conducted a multi-temporal mapping of seagrass cover, species and biomass in Moreton Bay using a semi-automated object-based image analysis approach and had accurate results. Joyce and Phinn [21] developing spectral index for mapping live coral cover using multispectral and hyperspectral imagery integrated with a coral spectral library, and performing Spectral transformation, Water depth optical modeling, and Derivative analysis. Eastwood et al. [22] application of global protocols for quantitative coral reef health monitoring by considering the influence of increased tourism activities by utilizing Google Earth as a technology to accommodate reef check survey points. Wicaksono et al. [10] applied machine learning and cross validation approaches for mapping benthic habitats with high accuracy results. Previous research has shown that mapping coastal resources is very important for the sustainability of regional development and environmental management.

This research took place in Gili Sumber Kima, Buleleng Regency, Bali. This small island has potential seagrass bed and coral reef ecosystems and, at the same time, a somewhat massive development of tourism activities. There have been no inventories of seagrass beds and coral reefs around Gili Sumber Kima to date, and consequently, management activities are less than optimal. In response to this, the study sought to analyze changes in seagrass cover and damages to the coral reef in Gili Sumber Kima using a multitemporal approach and Sentinel 2A-MSI imagery. This multitemporal analysis is expected to be able to identify the spatial or temporal patterns of change in seagrass cover over a specific period and pinpoint the contributing factors. The research implications include the production of data on seagrass bed and coral reef ecosystems (inventory) that can be used as the basis for monitoring and managing coastal ecosystems.

\section{METHODOLOGY}

\subsection{Study area}

The research focused on Gili Sumber Kima, a very small island in Buleleng Regency, Bali Province, Indonesia (Figure 1). Geographically, it is located between $8^{\circ}, 111598-8^{\circ}$, $130138 \mathrm{~S}$ and $114^{\circ}, 598284-114^{\circ}, 629114 \mathrm{E}$. It is one of the areas in Buleleng Regency that have abundant coastal resources, including seagrass beds, coral reefs, and fishery products.

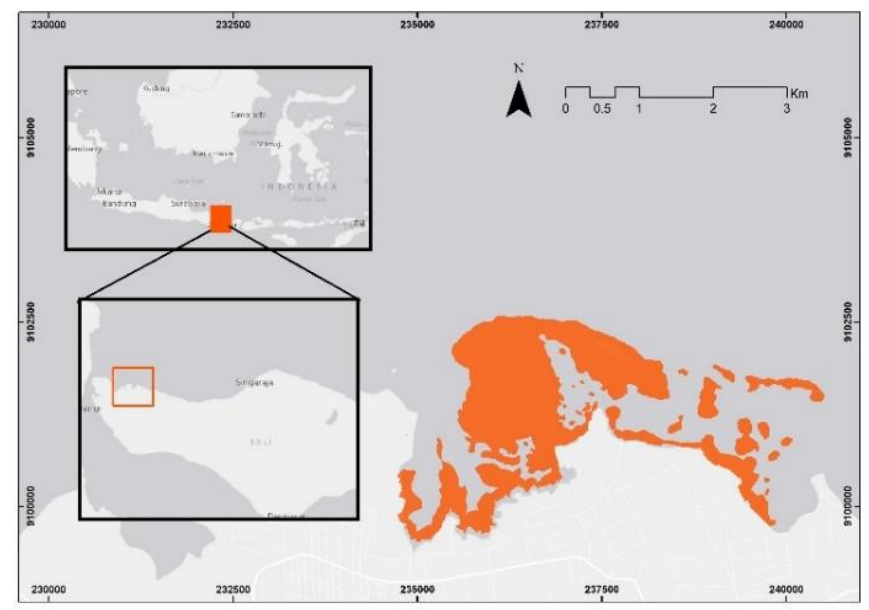

Figure 1. Study area

\subsection{Satellite image}

Sentinel-2A MSI $(10 \mathrm{~m})$, a satellite belonging to the European Space Agency (ESA), has nine channels consisting of different spectral and spatial resolutions, namely $10 \mathrm{~m}, 20$ $\mathrm{m}$, and $60 \mathrm{~m}$. This study used Sentinel-2A MSI images with a spatial resolution of $10 \mathrm{~m}$, which has four channels, i.e., blue, green, red, and near-infrared (Table 1). This type of image was selected because each of its channels has a range of wavelengths that can accommodate the application of remote sensing for mapping objects in shallow coastal waters [23].

\subsection{Data analysis}

The data processing consists of several steps. The first step was image corrections, followed by field data acquisition, image classification, bathymetry modelling, change detection, coral condition mapping and map validation (Figure 2). 
Table 1. Sentinel-2A MSI image characteristics [24]

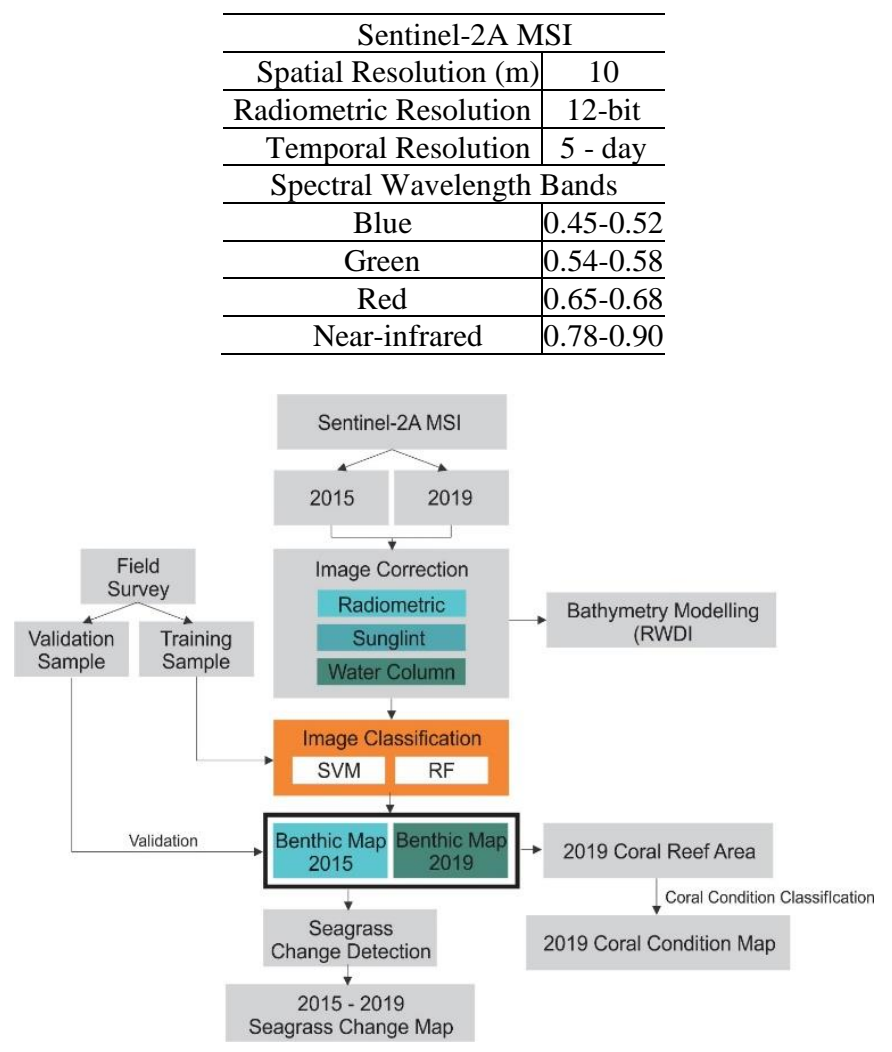

Figure 2. Research flow chart

\subsubsection{Radiometric correction}

Remote sensing imagery contains several interferences from the atmosphere and the sensor during the recording. These interferences produce noises that can affect the process of object identification and image analysis and, consequently, decrease the accuracy of the products. For these reasons, satellite images need prior corrections to minimize the noises. Image correction comprises several stages, namely conversion of digital number (DN) to Top of Atmosphere (TOA) radiance, conversion of TOA radiance to TOA reflectance, and atmospheric correction to produce images with a surface reflectance level. Sentinel-2 MSI imagery has incorporated the first two stages (TOA reflectance), meaning that the products only require an atmospheric correction. Generally, atmospheric correction consists of a variety of methods (FLAASH, 6S, Dark Object Subtraction (DOS), Regression). This study employed the Dark Object Subtraction because, compared with the other methods, it is the most straightforward and efficient. So far, the other atmospheric correction methods have exhibited no significant effects on the results of the analysis $[25,26]$.

\subsubsection{Sunglint correction}

Sunglint is a glassy reflection effect on the surface of calm water due to the influence of sunlight. This effect causes pixel error in remote sensing imagery, especially when the images are used in the mapping of shallow or deep waters with inherent optical properties. Sunglint complicates the identification process because the image is blocked by a specular reflection on the surface of the water. Sunglint needs to be minimized or corrected so as to improve the quality of the maps produced. This study used the method developed by Hedley et al. [27] because it is simpler, and it produces better results than other sunglint correction methods [28].

$$
R v i s^{\prime}=R v i s-b i(R N I R-R \min (N I R))
$$

Rvis': de-glint bands

Rvis: visible bands

$b i$ : Training sample gradient regression between NIR with visible bands

$R_{N I R}$ : NIR band

$R \min (N I R)$ : minimum pixcel value of NIR band

\subsubsection{Water column correction}

Water column correction, an approach in image processing, minimizes the influence of electromagnetic energy attenuation in the water column. This correction is usually applied to remote sensing images used in the detection of objects in optically shallow waters because it can improve the accuracy of the maps produced [29]. For water column correction, this study employed the method developed by Lyzenga [30], which is among the simplest methods that can give better results [31].

$$
\operatorname{Ij}(Y i i j)=\ln (L i)-[(K i / K j) \cdot \ln (L j)]
$$

Ij(Yij): Water column corrected band

$\ln (\mathrm{Li})$ : Deglint band logs with a lower wavelength

$\mathrm{Ki} / \mathrm{Kj}$ : attenuation coefficient

$\ln (L j)$ : Deglint band logs with a higher wavelength

$$
a=(\sigma i-\sigma j) / \sigma i j
$$

$$
K i / k j=a+\sqrt{ }(\measuredangle(a) \wedge 2+1))
$$

$\sigma i$ : A band variant with a lower wavelength $\sigma j:$ A band variant with a higher wavelength бij: Covariance between $\mathrm{i}$ and $\mathrm{j}$ band $a$ : The value obtained from the Eq. (3)

\subsection{Field data acquisition}

The data in the field were collected by photo transect [12, 18]. This technique is known to be very efficient in terms of time, energy, cost, and the amount of the data acquired. Photos of benthic habitats were captured with underwater cameras while snorkeling in optically shallow waters. These cameras were set at the same time to enable the geotagging process between photos and the GPS coordinates of the captured objects using DNR Garmin software. The collected-samples were recorded as point, and each photo was interpreted using CPCe 4.0 software. For each photo, 24 points were randomly placed across the photo.

\subsection{Satellite image classification}

According to the Indonesian National Standard (SNI) 7716: 2011 , there are four major classes of benthic habitats, namely substrate, coral reef, seagrass, and macroalgae. This scheme of classification was applied to each year of available images to estimate the areas and distributions of seagrass and coral reef. The area of the two benthic habitats in each year was used as the basis in the analysis of changes or dynamics of seagrass distribution. Meanwhile, the distribution of coral reefs was used to describe the condition of coral reefs in Gili Sumber Kima. The supervised classification was processed with two algorithms, which were Random Forest (RF) and Support 
Vector Machine (SVM). Both RF and SVM were run using EnMAP-Box. Machine-learning techniques such as SVM and RF are more suitable to accommodate these issues and have also been adapted and showed promising accuracy result [10] Recently, application of machine learning classification algorithms such as SVM and RF have been adapted and show promising accuracy. The use of the SVM and RF algorithms is not only limited to finding the suitable classification algorithm, but also finding the most suitable map modeling to adapt the models at the other area. The main purpose of applying machine learning is to build an automation model for mapping coral reefs and seagrasses with the consideration of more complex data sets to be more consistent and widely usable. The hope is that this development can facilitate the acquisition of blue carbon information, to assess and maintain coastal ecosystem services [32].

\subsubsection{Random Forest}

Random Forest is a machine learning in which the classification process is based on tree set units. Each tree unit determines the class of a satellite image pixel based on the sample data inputted to the classification [33]. Random Forest is a combination Regression Tree algorithm that performs predictions based on independent random sample dependence [33]. Random Forest predicts the model by generalizing errors, through correcting errors repeatedly in each tree, to fix (random split) the model to consistently produce high accuracy results [34]. The use of Random Forest in mapping is able to provide good results and reduce noise and outlayers in random split samples [35]. The parameter function used in RF is the EnMAP-Box default setting using 100 Number of trees, feature square root and Gini coefficient for impurity function. The algorithm of Random Forest was used in the study because it has been proven to produce high accuracy compared to other classification algorithms $[9,36]$.

\subsubsection{Support vector machine}

Support Vector Machine (SVM) is a non-parametric algorithm of supervised classification. SVM works by finding a hyperplane that can separate several datasets inputted to the algorithm into a predetermined number of classes [9]. SVM has two kernels, the setting of the kernel width and the polynomial degree. The kernel can be set to control the acceptable margin of error of the classification [9, 37]. The parameters used in SVM are the EnMAP-Box default setting using the Gaussian RBF kernel with 3 numbers of folds cross validation. The study employed the SVM algorithm because in coastal resource mapping applications, including seagrass beds and coral reefs, the SVM algorithm is increasingly being used because it is able to provide high accuracy compared to other algorithms [38-40].

\subsection{Change detection}

Multitemporal aspects (time series) are the pivot of analysis of change because they incorporate initial or before $(\mathrm{t} 1)$ and after $(\mathrm{t} 2)$ conditions. Changes are defined from the transition of the distribution of dominant objects between $\mathrm{t} 1$ and $\mathrm{t} 2$ [41]. t1 in this study is 2015 and $t 2$ is 2019 . Benthic habitat maps obtained in 2015 and 2019 were then analyzed for change detection to determine which benthic composition had changed. This study used a Change Analysis Modeler to find out any changes in seagrass cover from 2015 until 2019.

\subsection{Accuracy assessment}

In this study, the accuracy test, i.e., a confusion matrix [42], sought to determine the accuracy of the maps produced. The input of a confusion matrix is the validation set outside the training data that is analyzed against the image classification results to describe the precision of the classification model. Meanwhile, the outcomes are accuracy and kappa values. Accuracy is the ratio of the correctly classified validation data to the total validation data. Kappa values represent the proportion of the accurately classified validation data based on the accumulation of agreement values in each class.

\section{RESULT AND DISCUSSION}

\subsection{Benthic habitat mapping}

The benthic habitats were mapped using the major classes proposed by the Indonesian National Standard (SNI) and the technical guidelines for benthic habitat mapping issued by the data managers of P2O LIPI. Here, the major classes are substrate, coral reef, macroalgae, and seagrass. Benthic habitat maps were created by the multispectral classification of images that went through sunglint and water column corrections using the RF and SVM algorithms. The maps processed from images in two different years present different distributions and areas (Figure 3). From 2015 until 2019, the benthic habitats were experiencing some changes in their distributions and areas. The most noticeable change was the substrate. In 2015, the substrate cover was significantly wider than in 2019. This area reduction is believed to be the effect of climate, wave energy, current, and highly dynamic coastal waters $[43,44]$. The same case applies to seagrass and coral reef covers. However, there was a misclassification in 2015 because the reflection of the coral reef was very similar to that of seagrass. Also, in 2019, the area of macroalgae had decreased, although not significantly.

Each classification result had different values of accuracy. $\mathrm{RF}$ algorithm with water column-corrected images as the channel input produced a classification of the 2019 data with the highest accuracy, $68.3 \%$, and a kappa value of $52.89 \%$. Meanwhile, in 2015, the highest accuracy $(62.94 \%$, with a kappa value of $42.25 \%$ ) was produced by the SVM algorithm with sunglint-corrected images as the channel input (Table 2). The difference in accuracy was caused by the validation data that were sourced from 2019, meaning that when they were applied to the 2015 data, many validation points were either mismatched or non-existent. There was a high possibility that one point showed a benthic object in 2015 but a different one in 2019. As a result, the accuracy of the classification model in 2015 was lower than in 2019. This study is limited by the absence of temporal validation data for the year 2015. It assumed that the 2019 data could represent the appearance of benthic objects in 2015, as evidenced by the insignificant difference between the accuracies of the 2015 and 2019 classifications, i.e., 5-6\%. The results of the experiment on benthic habitat classification are presented in Table 2 .

Judging from the producer and user accuracies (Figure 4), seagrass cover from the best benthic habitat map in each year can be classified at high accuracy. In 2015, the map of the seagrass cover, which was produced using the SVM algorithm and sunglint-corrected images, had an accuracy of $+-70 \%$. Meanwhile, in 2019, through the RF algorithm and water 
column-corrected images, the mapped seagrass cover had an accuracy of $+-83 \%$. These figures demonstrate the ability of Sentinel-2A MSI as a data source that can classify marine objects correctly.
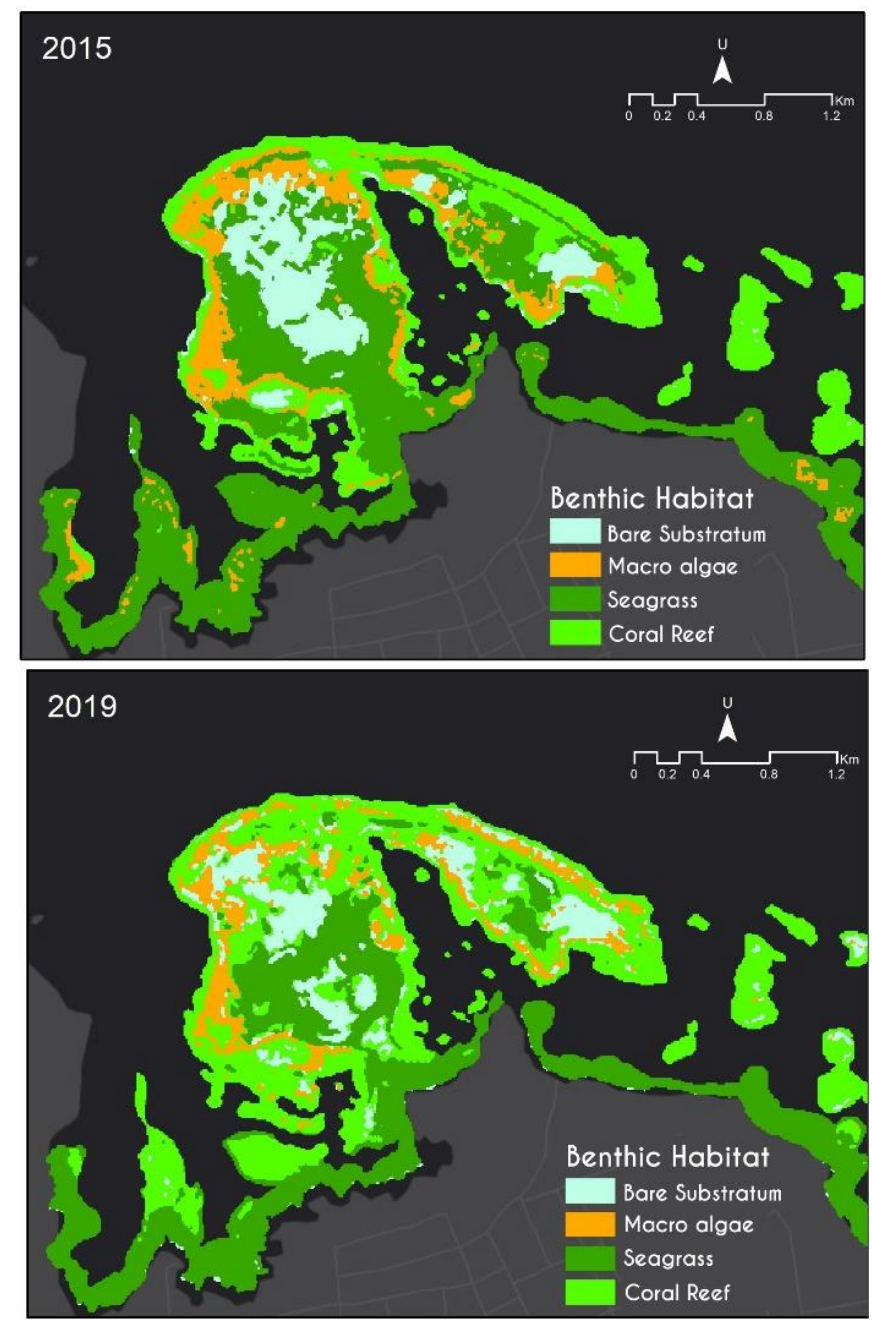

Figure 3. Benthic habitat map

Table 2. Benthic habitat map accuracy result

\begin{tabular}{ccccc}
\hline Tahun & \multirow{2}{*}{ Band } & $\begin{array}{c}\text { Machine Learning } \\
\text { Algorithm }\end{array}$ & OA (\%) & Kappa \\
\hline \multirow{3}{*}{2015} & \multirow{2}{*}{ DII } & RF & 42.66 & 3.42 \\
\cline { 2 - 5 } & \multirow{2}{*}{ Deglint } & SVM & 46.85 & 0.00 \\
\hline \multirow{2}{*}{ Tahun } & \multirow{2}{*}{ Band } & RF & 62.24 & 42.63 \\
& \multirow{2}{*}{ Machine Learning } & OA (\%) & \multirow{2}{*}{ Kappa } \\
\hline \multirow{3}{*}{2019} & \multirow{2}{*}{ DII } & Algorithm & 62.94 & 42.25 \\
\cline { 2 - 5 } & \multirow{2}{*}{ Deglint } & RF & 68.39 & 52.89 \\
& & SVM & 38.06 & -2.86 \\
\hline
\end{tabular}

Based on the overall results of benthic habitat maps, DII bands have the lowest accuracy result. The benthic mapping concept emphasizes the variation aspects of pixel values on each object so the model can run optimally. Thus, when the pixel variation is very low, the model will saturate and cause a large error. In the DII band, the image pixel shows the object index value. Because each benthic object has similar DII values to another (low pixel variation). Thus, when the model is applied, saturation occurs, which produces high error in the maps. Another thing that affects the low accuracy of the 2015 benthic habitat map is the decreases of image quality when water column correction (DII) is applied (technical factors). The use of Sentinel-2 MSI images in very good clarity conditions, there is no need for additional correction or transformation treatments such as DII because it can worsen the pixel value of the image and decrease the accuracy [45].
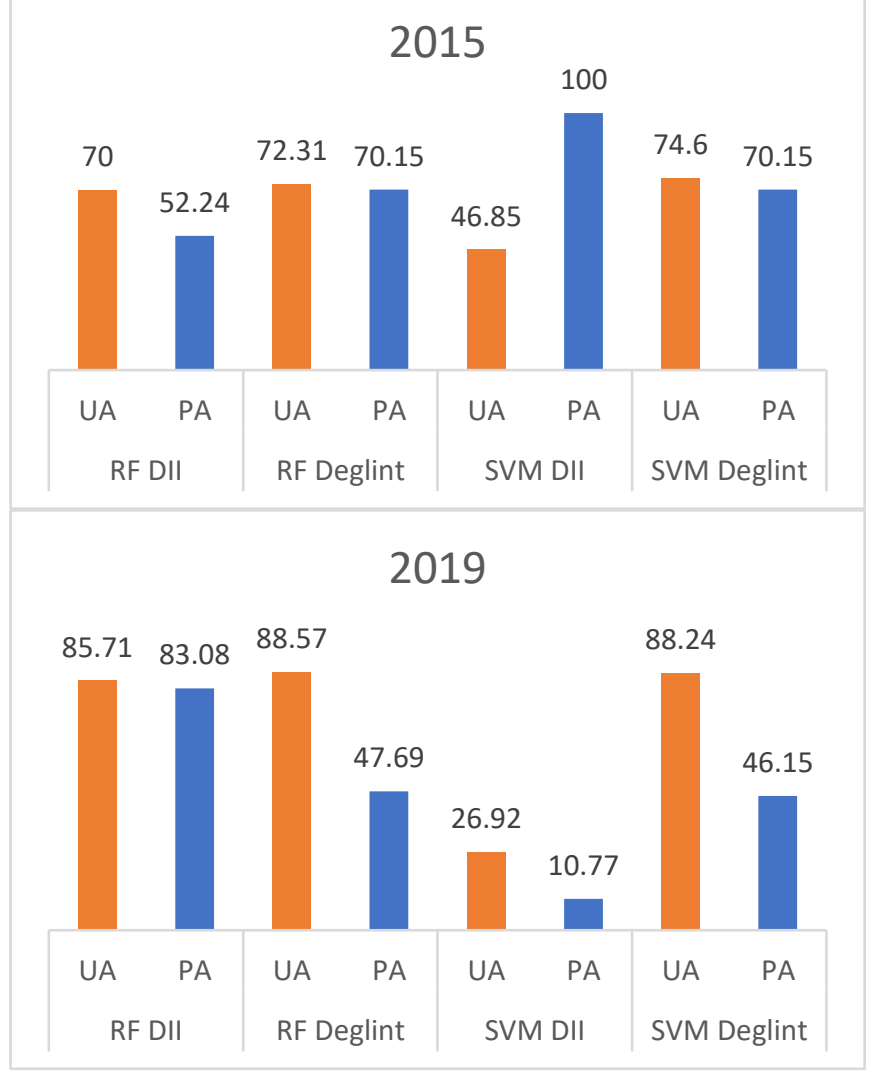

Figure 4. Seagrass producer's (PA) and user's accuracy (UA) map

Using a machine-learning algorithm, it is very possible to include various datasets as classification inputs, in order to obtain an accurate benthic habitat map. Thus, the machinelearning algorithm may produce a classification result at the maximum image descriptive resolution. Regarding the machine learning classification algorithm, variations in the function parameters of both SVM and RF do not have a significant difference in results. This can be proven through a similar study using RF and SVM. [46] conducted an RF experiment for mapping seagrass beds. The scenarios used are five number of trees scenario, 25, 50, 75, 100, and 500. In addition, functions features, i.e., Square root of all features and Log of all features, and impurity in a node, i.e., Gini coefficient and Entropy. Based on the RF experiments, the results obtained are not very significant, its only differed 0.8 to $5.8 \%$ of the overall accuracy. This indicates that RF is a more consistent machine learning classification algorithm.

For the SVM algorithm, if the image quality is in very good condition, the results obtained will not have significant accuracy with RF. Both after applying kernel variations and the number of folds used. What is found in this research is that SVM is very sensitive with poor image quality (high noise). Therefore, the results obtained have lower accuracy than RF. However, RF provided more consistent performance in terms 
of spatial distribution and its similarity to the field condition compared with SVM [10]. As a suggestion for further research, especially machine learning algorithms so that they can be widely used. It is very important to pay attention to the band used. For instance, the quality of the corrected image of the water column is very subjective and depends on the condition of each area's waters. When the conditions are not favorable, the resulting model tends to give less good results. So that the best input band to use is Surface reflectance and deglint bands.

\subsection{Seagrass change detection}

Change detection helps to identify changes in seagrass cover from 2015 until 2019. This analysis can straightforwardly pinpoint the direction of the observed changes. Figure 4 shows that the estimated seagrass cover had an accuracy of $+-70 \%$ in 2015 and $+-83 \%$ in 2019 . The classifications of seagrass cover had different accuracies because of many factors. From the data source, the contributing factors may include resolution, correction, data quality, and algorithm. The circumstances in the field may also be a factor, such as water clarity, seagrass depth, seagrass density, and sand substrate in the background.

In clear shallow waters, the sand substrate can simplify the identification process and improve the accuracy of the seagrass cover classification [13]. Sand and seagrass in clear shallow waters have contrasting reflections. The former has a light expression, while the latter is dark. With these characteristics, the seagrass and sand objects in the study area can be distinguished; therefore, the classified seagrass cover had high accuracy. Figure 5 shows the different distribution patterns of seagrass cover in 2015 and 2019. In the middle of the study area close to the sandbar, a significant difference was detected. In 2015, this point was a sand substrate, but in 2019 , it had transformed into seagrass. The seagrass cover decreased from 243.3 ha in 2015 (including misclassification) to 185.2 ha in 2019. This decline illustrates significant changes in seagrass cover.

The change detection analysis produced three directions of change, namely decreasing, increasing, and unchanging (Figure 6). In the case of seagrass, the area of coverage was decreased by 86 ha and increased by 27.9 ha, whereas no sign of changes was found in the other 157 ha. The unchanging state represents seagrass habitats with preserved conditions that are protected from coastal processes and dynamics. However, the total loss of the seagrass area (changed into sand substrates) was approximately three times greater than the increase. Unless mitigated soon, this situation will negatively affect marine ecosystems. In 2015, the spatial distribution of the seagrass cover was better than in 2019 . These changes are attributable to the hydrodynamic effects of waves and currents, as well as the influence of human activities. Cage culture and many other aquaculture practices, excessive exploitation of shellfish (clams), and blast fishing [47, 48] significantly affect the growth and development of seagrass cover in shallow waters. In the study area, many fish ponds have been built close to seagrass beds and coral reefs, and their number continues to grow. In the long term, this form of aquaculture brings about damages to seagrass cover, coral reefs, and fish habitats and deteriorates the quality of the waters. The interviews with the local community revealed that clam exploitation by bombs and crowbars were the leading cause of the damages in Gili Sumber Kima. According to the fishers, the perceived environmental damages included loss of fish and other marine organisms. This adversity reduced the total fishery products and threatened the continuity of fisher livelihoods. If this issue continues in the future, it will cause severe negative impacts on shallow-water habitats, especially seagrass cover.
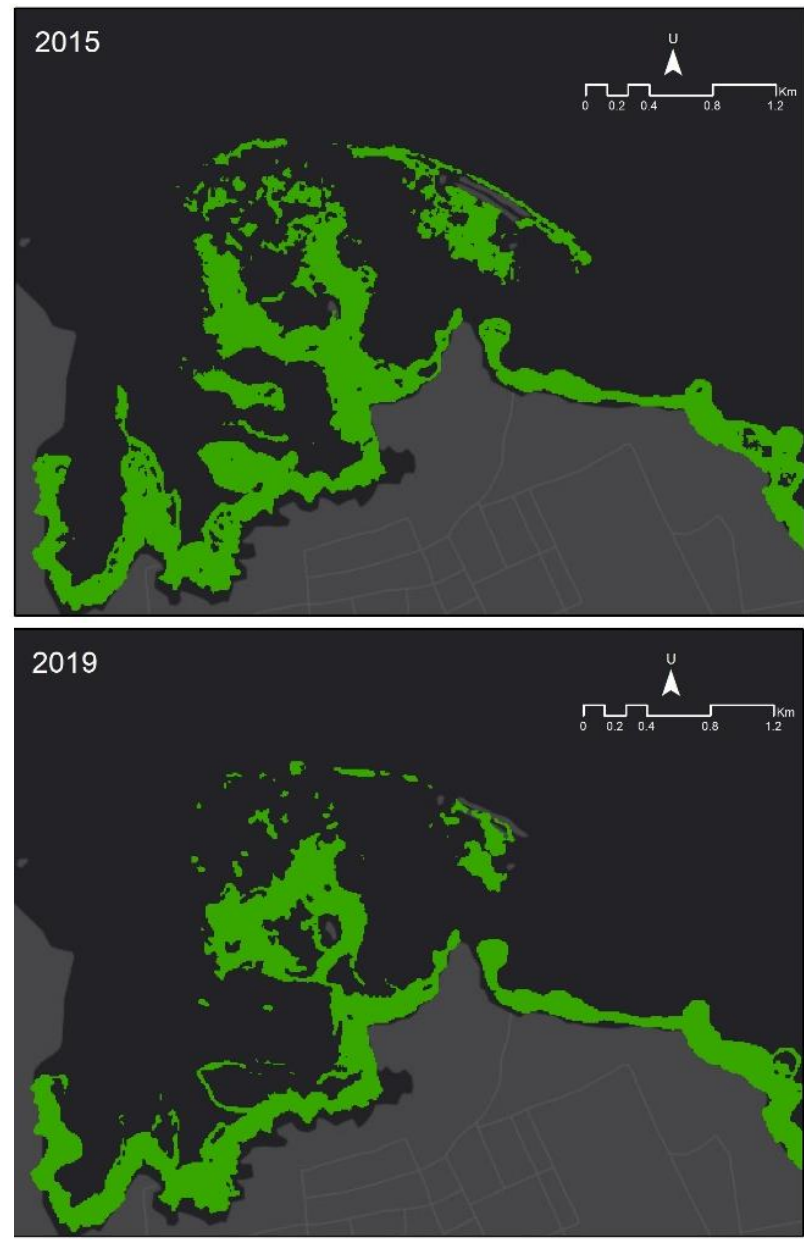

Figure 5. Seagrass cover map of 2015 and 2019

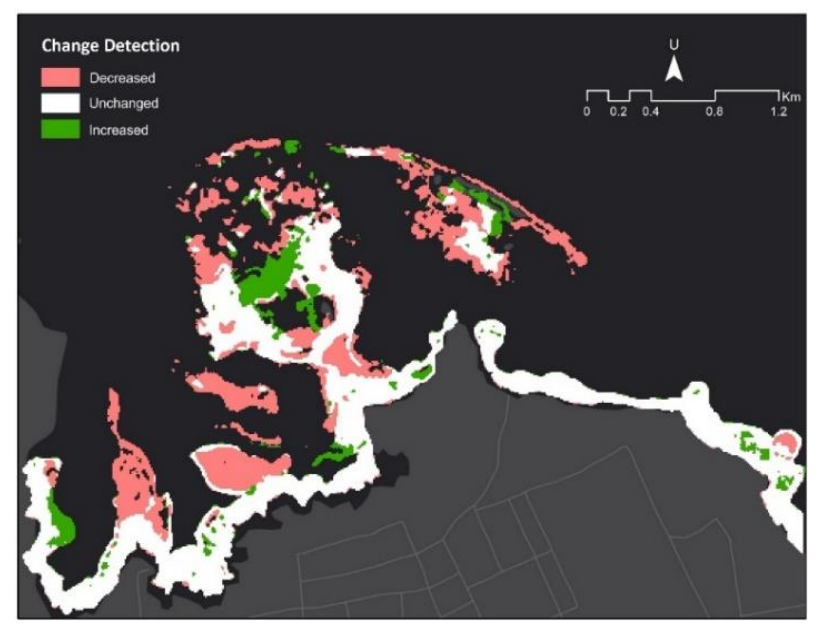

Figure 6. Seagrass change detection map

Changes in seagrass cover are also attributable to climatic factors (wind, waves, strong currents) [15]. When severe weather occurs, it causes direct physical damage to the seagrass cover as it stirs up the sediments and mixes them with the chemical waste from the residential and lodging areas. In this case, seagrass cover cannot grow optimally. According to $[2,48]$, there is a positive correlation between the extent of 
land-use conversion to built-up environments and the significance of the seagrass cover shrinkage. In the future, to avoid the emergence of negative impacts, the condition of the waters and benthic habitats needs to be preserved so as to allow seagrass beds to grow and develop optimally. A sustainably healthy ecosystem is believed to bring a variety of rare aquatic organisms, such as turtles and dugongs that highly depend on seagrass as their source of food. Provided that any human activities that worsen the condition of these environments are significantly reduced, the existence of these sea creatures can stabilize the marine environments. Another positive impact of a healthy ecosystem is that coral reefs can improve their state of health and natural functions as fish habitats. In the future, similar research is expected to be able to develop or utilize data on ecosystems and shallow-water biodiversity to observe the development trend or pattern periodically [13].

\subsection{Coral condition mapping}

The maps of coral reef cover created in this study have high accuracy. The SVM and RF algorithms produced the accuracies of $77-80 \%$ and $60-70 \%$, respectively (Figure 7 ). These percentages indicate that $60-80 \%$ of the estimated seagrass cover is closely similar to the actual condition in the field. The area of cover produced by the SVM algorithm has high accuracy and shows a similar distribution to the actual condition. Therefore, it was used as the boundary in the analysis of coral reef condition.

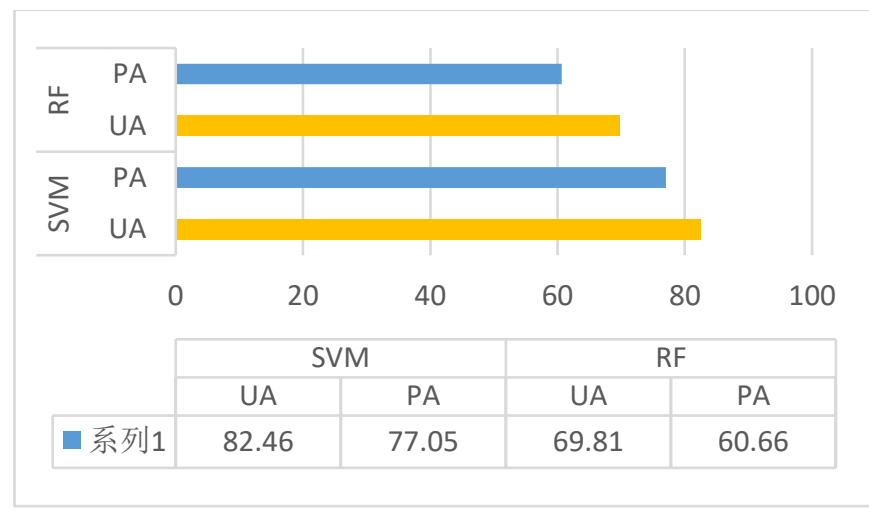

Figure 7. Graphic of Coral Reef Condistion Class Producer's (PA) and User's Accuracy (UA)

Based on the classification scheme, the mapping was carried out using two classes of coral reefs, namely damaged and healthy coral reefs. Either class was decided by comparing the percent of live coral reef cover with the dead one. If the percent of live coral reef cover is greater than the dead one, the object is classified as healthy. On the contrary, if the percent of dead coral reef cover is higher than the live one, the object falls into the category of damaged. The coral reef conditions were mapped using Sentinel-2 MSI images, whose level of correction already includes surface reflectance. At this level, the pixel value of the image can represent different coral reef conditions in the field, and in that year, the primary data were collected in the field. The results of the water column correction on Sentinel-2 MSI images were not used in the mapping because this correction would change the value of the image into the depth invariant index. The depth invariant index is not suitable for the mapping of coral reef conditions because it is significant in different types of objects. For instance, the damaged and healthy coral reefs in water column-corrected images have similar index values. Therefore, discriminating between the two states of health would be difficult. Meanwhile, using surface reflectance imagery, the conditions of coral reefs can be distinguished easily because the reflections correspond to the actual conditions of the objects in the field. Using a rather strong water column correction can cause damages or severe noises on the image and lead to a complex identification process and reduced accuracy [45].

The map of the coral reef conditions showed a fairly unique distribution. The damaged coral reefs were located in shallow waters, whereas the healthy ones were in deep waters (Figure 9). With $42 \%$ accuracy and a kappa value of 0.38 , this map had a relatively low precision. This result is caused by the lack of sample size that causes some points to be misclassified during the calculation of the accuracy. Besides this is due to the similarity of pixels between coral reefs with different percent cover. The different depths also affected the value of the coral reef pixels. The deeper the coral reef, the lower the pixel reflectance and identified as a high coral live cover, and vice versa. The coral percent cover mapping results have accuracy and other problems that are comparable to those found in some studies [21]. Until now, coral percent cover mapping has rarely been attempted due to the low accuracy of the results. Based on the distribution pattern, the estimated state of the coral reefs resembled the actual condition-i.e., the damaged reefs were found in shallow waters but the healthy ones were in deep waters. A total of 1397 ha of coral reefs were damaged, while the healthy ones covered an area of 1505 ha (Table 3). In other words, almost $50 \%$ of the coral reefs around the waters of Gili Sumber Kima are damaged.

Table 3. Area of coral cover condition

\begin{tabular}{cc}
\hline Coral Class & Area (ha) \\
\hline Healthy Coral & 1505.56 \\
Dead Coral & 1397.27 \\
\hline
\end{tabular}

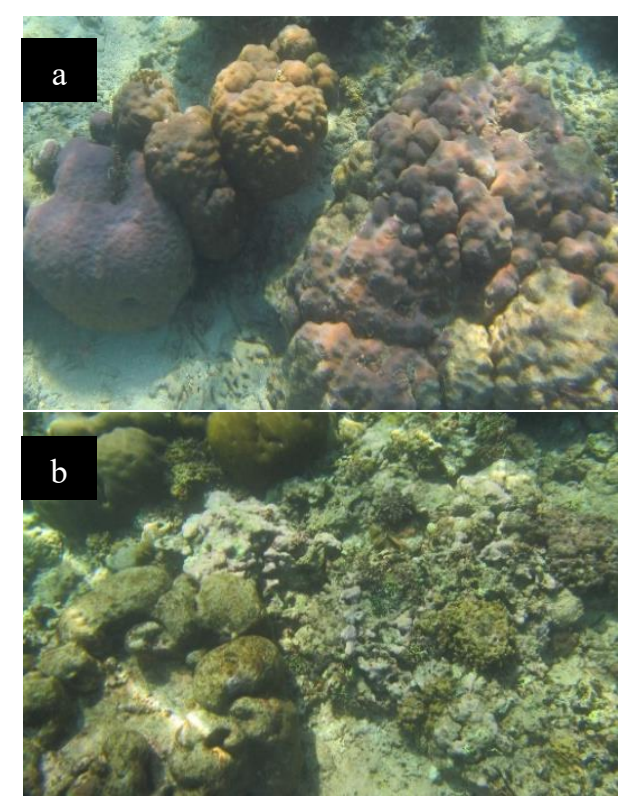

Figure 8. Coral condition: a) Healthy coral; b) Dead coral source: Field data (2019)

Massive human activities in coastal areas are known to cause damages to coral reefs. Humans affect their surroundings through the rapidly growing tourism activities, 
land-use conversion to settlements and tourism services, aquaculture, marine traffics, construction of infrastructure, and destructive fishing [49, 50]. The distribution of the damaged coral reefs in the shallow waters (Figure 8) seems to associate with the floating net cages, which cover a relatively large area close to the coral reefs. The intensive activities in this form of aquaculture affect the surrounding aquatic environments, leading to stressed and eventually damaged coral reefs. Also, most floating net cages are anchored or tied to coral reefs to prevent them from drifting. Aside from this cage culture, damages to coral reefs are induced by clam overexploitation and severe weather. Coral reefs are home to kima or giant clams that are protected and have high economic values. Around the waters of Gili Sumber Kima, these clams are harvested massively by damaging the coral reefs using crowbars. Consequently, many coral reefs are damaged in the process, especially in the north.

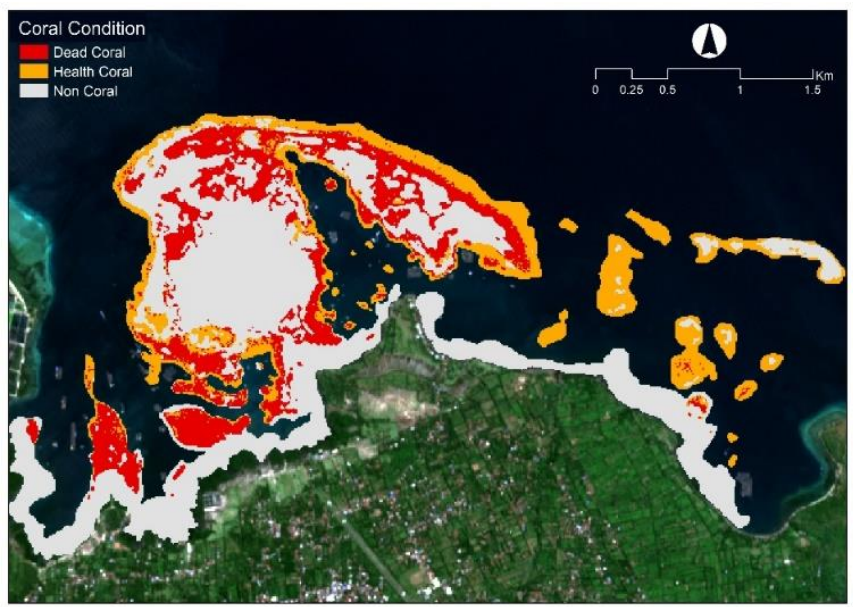

Figure 9. Coral condition map

Severe weather that hits the northern coast of Bali has caused many changes in the coastal region. Gili Sumber Kima, part of the northern coast, has to suffer a considerable impact, particularly on the sustainability of its coastal ecosystems. Severe meteorological phenomena accumulate sediments in shallow waters, and sediments are known as one of the biggest enemies of coral reefs. Sediments block the sunlight from reaching the polyps on top of the coral reefs and, thereby, prevent the process of photosynthesis and hinder the search of nutrients for the growth of the coral skeleton. Over time, the coral reefs are damaged, and eventually, die [5]. Damages to coral reefs around the waters of Gili Sumber Kima demonstrate that the direction of the changes in coastal water environments and ecosystems is negative. These negative changes are, for instance, decreased values of biodiversity and fishery products, deteriorated quality of the aquatic environment, and the loss of objects that can dissipate the wave and current energy. All of these problems arise because coral reefs can no longer function as the primary ecosystem that supports coastal waters [44]. Unlike the northern coast, the waters in the east are dominated by healthy coral reefs because they are located far from the location of human occupations (i.e., cage culture). Moreover, in these protected waters, clam exploitation and diving tourism are restricted, allowing the coral reefs to grow sustainably without any threats of damages. Mapping the condition of coral reefs provides an abundant amount of information that acts as the basis for determining the priority areas for coral reefs monitoring and management [4, 9]. It also assists the stakeholders in taking actions straightforwardly according to the prepared conservation programs

\subsection{Bathymetry mapping}

The topographic conditions of the shallow waters of Gili Sumber Kima are divided into four morphological forms of coral reef, namely reef flat, reef crest, fore reef, and patch reef. Reef flats are dominated by substrate, seagrass, and macroalgae, while reef crests, fore reefs, and patch reefs are dominated by coral reefs. These forms can be identified by calculating and characterizing the depth of the coastal waters. The spatial data on water depth, or commonly called bathymetry, can be extracted from remote sensing imagery using various modeling methods. These methods rely on primary data (measurement in the field) and/or qualitative estimates, which are based on the characteristics of the depth range identifiable from remote sensing images. Bathymetry modeling can be performed using many techniques, including band ratio, single band, and Relative Water Depth Index (RWDI) [51]. Because the bathymetry information is not available in the study area, single band and band ratio are therefore inapplicable. To produce the spatial data of relative bathymetry, the research employed RWDI. The principle of RWDI is the spectral response of objects at the bottom of the water to visible and near-infrared channels. RWDI produces bathymetry with relative depth information, as indicated by the ratio of 0 (shallow waters) and 1 (deep waters) [52]. The bathymetry model showed that shallow waters dominated the coastal waters of Gili Sumber Kima. The shallow waters are shown in red to yellow, while deep waters are depicted in cyan to bluish color (Figure 10).

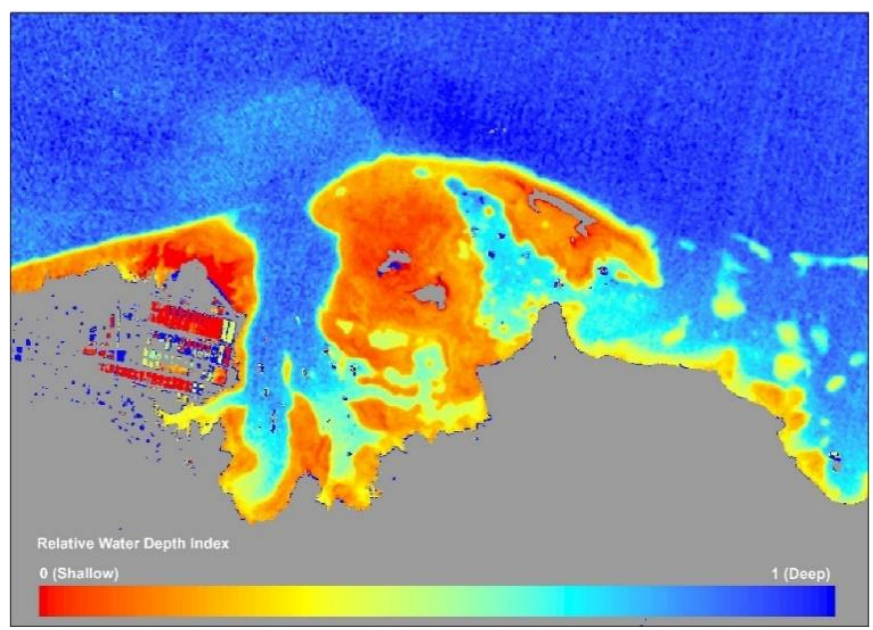

Figure 10. Relative water depth index (RWDI) map

The 3-dimensional visualization proved that the bathymetry model corresponded to the actual depth in the field. There were slightly different morphological appearances in the 3dimensional view of the eastern waters. Patch reefs, where coral reefs grew, were dominant in these waters. Topographically, their form resembled small hills that were separated from each other (Figure 11). There was a slight error in the modeling results, especially on a small island in the middle of the shallow water. The waters around the small island had a very clean sand substrate, and the field survey showed that they were 0.3 to $1 \mathrm{~m}$ in depth. However, because the pixel values were severely bright, the RWDI model read 
these features as very shallow waters. Another error was found in waters with depths of $>10 \mathrm{~m}$ because the RWDI model read these features as the saturation of the pixel values. If viewed from satellite images, deep waters produce a similar spectral response. In this case, the RWDI model reads the response as saturation and perceives the pixel values as having a relatively similar depth (1).

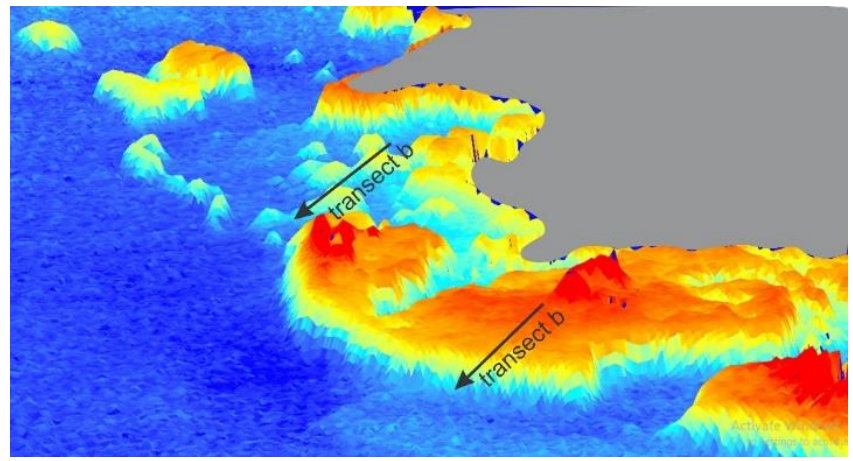

Figure 11. 3D Visualization of RWDI Bathymetry

The cross-sectional profile of the modeled bathymetry (Figure 12) was formed with a transect from shallow to deep waters. It depicted the topographical conditions of this segment. In this study, the transect was an imaginary line cutting through the northern part of the shallow waters in Gili Sumber Kima, as shown in Figure 11. This part of the waters was selected because the field survey was carried out intensively in this location. In other words, verifying the results of the modeling with the actual conditions would be straightforward. The cross-sectional profile of the bathymetry of shallow waters in Gili Sumber Kima is presented in Figure 12.

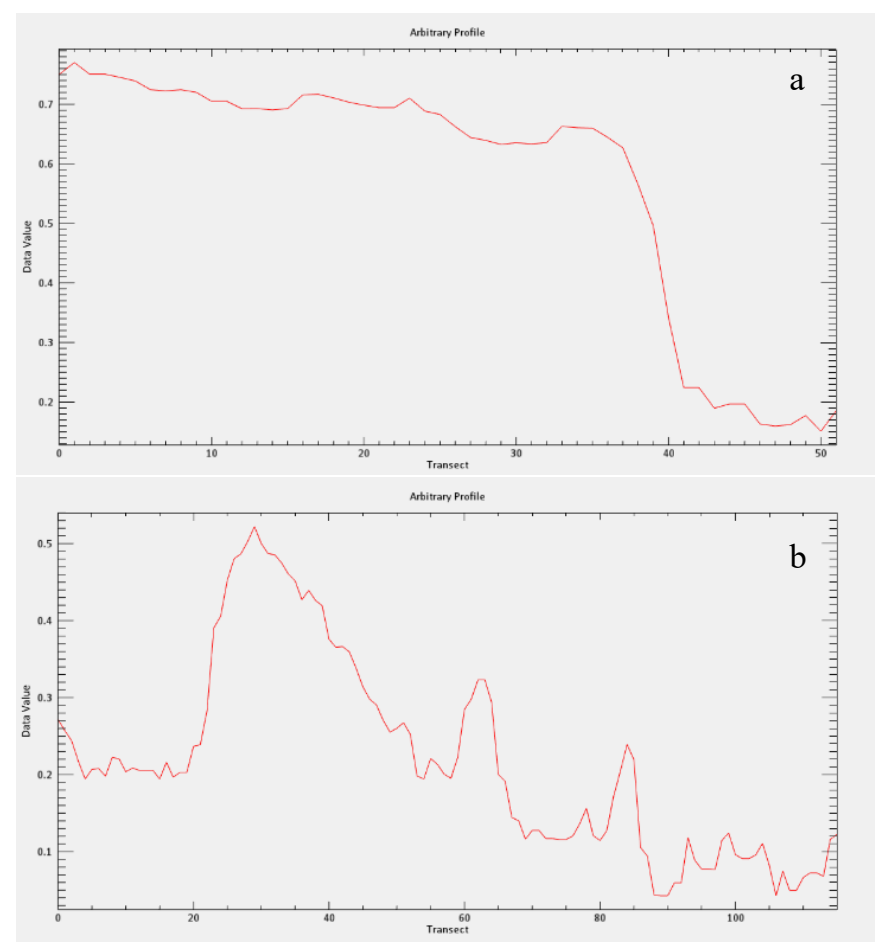

Figure 12. Bathymetry cross-profile: a) transect a and b) transect b
According to the cross-sectional profile, the morphological zonation of the coral reefs is in line with the discussion at the beginning of Point 3.4. The morphology is divided into four forms, namely reef flat, reef crest, fore reef, and patch reef. Reef flats have a relatively flat topography, while reef crests are the transition zone between reef flats and deep waters (cliff). Fore reefs are indicated by steep topography overlooking open sea waters. Patch reefs have similar topography to a small hill with a hilltop that is not too high (Figure 11). So far, bathymetry mapping using remote sensing imagery has been able to produce accurate data, with the standard errors ranging between 0.79 and $1.05 \mathrm{~m}$ [53-55]. The spatial information of bathymetry is essential in coastal area management and planning. Bathymetry shows which waters have the potential for fisheries using the habitat approach. Also, it functions as supporting data in navigation and port development plans and identifies safe locations for the ship's mooring. Therefore, rapid acquisition of bathymetric data from remote sensing imagery is one of the breakthroughs in coastal area management and development.

\section{CONCLUSIONS}

The maps of seagrass cover and coral reefs produced in this study have high accuracy. The accuracies of the seagrass cover are $+-70 \%$ in 2015 and $+-83 \%$ in 2019 , while the accuracy of the coral reef cover is up to $82 \%$. These percentages indicate that the estimated seagrass cover and coral reefs are reliable and can be used for analyzing shallow-water ecosystems, including the analysis of changes in seagrass cover and damages to coral reefs. Based on the multitemporal analysis of seagrass cover in 2015 and 2019, there are significant changes between the two years. In 2015, the seagrass cover was significantly wider than in 2019. In terms of area, the seagrass cover was increased by 27.9 ha and reduced by 86 ha, while the other 157 ha showed no changes. The transformation of seagrasses to sand substrates appears to dominate these changes. Seagrass covers that tend to change are located close to the cage culture and not protected from the hydrodynamic process of marine waters. The estimated condition of coral reefs has low accuracy, that is, $42 \%$, due to the lack of sample size on damaged coral reefs. The produced maps show that, spatially, 1397 ha of the coral reefs in Gili Sumber Kima is damaged, while the healthy coral reefs cover an area of 1505 ha. These findings show that the coral reefs are split almost equally $(50 \%)$ between the damaged and the healthy ones, or in other terms, the coral reefs seem to have suffered massive damages. Damages to the coral reefs are attributable to human activities, such as aquaculture, tourism, clam exploitation, destructive fishing, municipal waste from the surrounding residential and lodging areas, and severe weather

\section{ACKNOWLEDGEMENTS}

This paper has been written as part of collaborative research between the Faculty of Geography Universitas Gadjah Mada and the government of the Buleleng Regency in Bali. We would to thank the 2019 MPPDAS KKL group that helped each other during the field survey in Bali. We would also like to thank the anonymous reviewers for their helpful comments on this paper. 


\section{REFERENCES}

[1] Duarte, C.M., Borum, J., Short, FT., Walker, D.I. (2008). Seagrass ecosystems: their global status and prospects. In: Polunin N (Ed.) Aquatic Ecosystems, Cambridge: Cambridge University Press. http://dx.doi.org/10.1017/CBO9780511751790.025

[2] Waycott, M., Duarte, C.M., Carruthers, T.J.B., Olyamik, S., Calladine, A., Fourqurean, J.W., Heck, K.L., Hughes, A.R., Kendrick, G.A., Kenworthy, W.J., Short, F.T., Williams, S.L. (2009). Accelerating of loss seagrass across the globe threatens coastal ecosystems. In Proceedings of the National Academy of Science. https://doi.org/10.1073/pnas.0905620106

[3] P2OLIPI. (2017a). Status Padang Lamun Indonesia. P2O LIPI, Jakarta.

[4] Reid, C., Marshall, J., Logan, D., Kleine, D. (2009). Coral Reef and Climate Change: The Guide for Education and Awareness. Queensland: Coral Watch: The University of Queensland.

[5] P2OLIPI. (2017b). Status Terumbu Karang Indonesia. P2O LIPI, Jakarta.

[6] P2O LIPI. (2018). Status Terumbu Karang Indonesia. P2O LIPI, Jakarta.

[7] KLHK. (2004). Keputusan Menteri Lingkungan Hidup No.200 tahun 2004 Tentang Kriteria Baku Kerusakan dan Pedoman Penentuan Status Padang Lamun.

[8] KLHK. (2001). Keputusan Menteri Lingkungan Hidup No.4 Tahun 2001 tentang Kriteria Baku Kerusakan Terumbu Karang.

[9] Zhang, C. (2014). Appliying data fusion techniques for benthic habitat mapping and monitoring in coral reef ecosystem. ISPRSJournal of Photogrammetry and Remote $\quad$ Sensing, $\quad 104$ : 213-223. http://dx.doi.org/10.1016/j.isprsjprs.2014.06.005

[10] Wicaksono, P., Aryaguna, P.A., Lazuardi, W. (2019). Benthic habitat mapping model and cross validation using machine-learning classification algorithms. Remote $\quad$ Sensing, 11 : 1-24 http://dx.doi.org/10.3390/rs11111279

[11] Fornes, A., Basterretxea, G., Orfila, A., Jordi, A., Alvarez, A., Tintore, J. (2006). Mapping Posidonia oceanica from IKONOS. SPRS Journal Photogrammetry Remote Sensing, 60(5): 315-322 http://dx.doi.org/10.1016/j.isprsjprs.2006.04.002

[12] Roelfsema, C., Phinn, S.R., Joyce, K.E. (2006). Evaluating Benthic survey techniques for validating maps of coral reefs derived from remotely sensed images. Proceeding of 10th International Coral Reef Symposium, pp. 1771-1780.

[13] Lyons, M., Phinn, S., Roelfsema, C. (2011). Integrating quickbird multi-spectral satellite and field data: mapping bathymetry, seagrass cover, seagrass species and change in Moreton Bay, Australia in 2004 and 2007. Remote Sensing, 3: 42-64. http://dx.doi.org/10.3390/rs3010042

[14] Godet, L., Fournier, J., vanKatwijk, M.M., Olivier, F., LeMao, P., Retiere, C. (2008). Before and after wasting disease in common eelgrass Zostera marina along the French Atlantic coasts: A general overview and first accurate mapping. Dis Aquat Org, 79: 249-255. http://dx.doi.org/10.3354/dao01897

[15] Williams, R.J., Meehan, A.J. (2004). Focusing management needsatthe subcatchment level via assessments of change in the cover of estuarine vegetation, Port Hacking, NSW, Australia. Wetland Ecology Management, 12: 499-518. http://dx.doi.org/10.1007/s11273-005-3948-y

[16] Kendrick, G.A., Aylward, M.J., Hegge, B.J., Cambridge, M.L., Hillman, K. (2002). Changes in seagrass coverage in Cockburn Sound, Western Australia between 1967 and 1999. Aquatic Botany, 73(1): 75-87. http://dx.doi.org/10.1016/S0304-3770(02)00005-0

[17] Bell, D., Berelov, M.S., Young, P. (2014). Historical seagrass mapping in Port Phillip bay, Australia. Journal Coast Conservation, 18: 257-272. http://dx.doi.org/10.1007/s11852-014-0314-3

[18] Phinn, S.R., Roelfsema, C.M., Leiper, I., Mumby, P.J. (2008). Mapping Coral reef benthic zones from highspatial resolution image segmentation and photo transect data. In Proceedings of the 11th International Coral Reef Symposium, Fort Lauderdale, FL.

[19] Roelfsema, C., Phinn, S., Jupiter, S., Comley, J., Albert, S. (2013). Mapping coral reefs at reef to reef-system scales, 10s-1000s $\mathrm{km}^{2}$, using object - based image analysis. International Journal of Remote Sensing, 34(18): 6367-6388 http://dx.doi.org/10.1080/01431161.2013.800660

[20] Roelfsema, C.M., Lyons, M., Kovacs, E.M., Maxwell, P., Saunders, M.I., Samper-Villarreal, J., Phinn, S.R. (2014). Multi-temporal mapping of seagrass cover, species, and biomass: A semi-automated object based image analysis approach. Remote Sensing of Environment, 150: 172187. http://dx.doi.org/10.1016/j.rse.2014.05.001

[21] Joyce, K.E., Phinn, S. (2013). Spectral index development for mapping live coral cover. Journal of Applied Remote Sensing, 7(1): 1-20. http://dx.doi.org/10.1117/1.JRS.7.073590

[22] Eastwood, E.K., Clary, D.G., Melnick, D.J. (2017). Coral reef health and management on the verge of a tourism boom: A case study from Miches. Dominican Republic. Ocean \& Coastal Management, 138: 192-204. http://dx.doi.org/10.1016/j.ocecoaman.2017.01.023

[23] Goodman, J.A., Purkis, S.J., Phinn, S.R. (2013). Coral Reef Remote Sensing: A Guide for Mapping, Monitoring and Management. New York: London: Springer.

[24] Suhet. (2014). Sentinel-2 User Handbook. ESA European Space Agency, Europe.

[25] Nazeer, M., Nichol, J.E., Yung, Y.K. (2014). Evaluation of atmospheric correction models and Landsat surface reflectance product in an urban coastal environment. International Journal of Remote Sensing, 35(16): 1-21. http://dx.doi.org/10.1080/01431161.2014.951742

[26] Wicaksono, P., Hafizt, M. (2017). Dark target effectiveness for dark-object subtraction atmospheric correction method on mangrove above $\neg$ ground carbon stock mapping. IET Image Processing, 12(4): 582-587. http://dx.doi.org/10.1049/iet-ipr.2017.0295

[27] Hedley, J.D., Harborne, A.R., Mumby, P.J. (2005). Technical note: Simple and robust removal of sun glint for mapping shallow-water benthos. International Journal of Remote Sensing, 26(10): 2107-2112. http://dx.doi.org/10.1080/01431160500034086

[28] Kay, S., Hedley, J.D., Lavender, S. (2009). Sun glint correction of high and low spatial resolution images of aquatic scenes: A review of methods for visible and nearinfrared wavelengths. Remote Sensing, 1(4): 697-730. http://dx.doi.org/10.3390/rs1040697

[29] Maritorena, S. (1996). Remote sensing of the water 
attenuation in coral reefs: A case study in french polynesia. International Journal of Remote Sensing, 17(1):

155-166.

http://dx.doi.org/10.1080/01431169608948992

[30] Lyzenga, D.R. (1978). Passive remote sensing techniques for mapping water depth and bottom features. Applied Optics, 17(3): 379-383. http://dx.doi.org/10.1364/AO.17.000379

[31] Zoffoli, M.L., Frouin, R., Kampel, M. (2014). Water column correction for coral reef studies by remote sensing. Sensors, 14(9): 16881-16931. http://dx.doi.org/10.3390/s140916881

[32] Wahyudi, A.J., Rahmawati, S., Irawan, A., Hadiyanto, H., Prayudha, B., Hafizt, M., Afdal, A., Adi, N.S., Rustam, A., Hermawan, U.E., Rahayu, Y.P., Iswari, M.Y., Supriyadi, I.H., Solihudin, T., Ati, R.N.A., Kepel, T.I., Kusumaningtyas, M.D.A., Salim, H.L. (2020). Assessing carbon stock and sequestration of the tropical seagrass meadow in Indonesia. Ocean Science Journal, 55: 85-97. http://dx.doi.org/10.1007/s12601-020-0003-0

[33] Breiman, L. (2001). Random forests. Machine Learning, 45: 5-32. https://doi.org/10.1023/A:1010933404324

[34] Dietrich, T. (1998). An experimental comparison of three methods for constructing ensembles ofdecision trees: Bagging, boosting and randomization. Machine Learning, 40: 139-157. https://doi.org/10.1023/A:1007607513941

[35] Schweider, M., Leltao, P.J., Sues, S., Senf, C., Hostert, P. (2014). Estimating fractional shrub cover using simulated enmap data: A comparison of three machine learning regression techniques. MDPI Journal Remote Sensing, 6(4): 3427-2445 http://dx.doi.org/10.3390/rs6043427

[36] Ma, L., Li, M.C., Ma, X.X., Cheng, L., Du, P.J., Liu, Y.X. (2017). A review of supervised object-based land-cover image classification. ISPRS Journal of Photogrammetry and Remote Sensing, 130: 277-293. http://dx.doi.org/10.1016/j.isprsjprs.2017.06.001

[37] Zhang, C., Selch, D., Xie, Z., Robert, C., Cooper, H., Chen, G. (2013). Object-based benthic habitat mapping in the florida Keys from Hyperspectral imagery. Estuarine, Coastal and Shelf Science, 134: 88-97. http://dx.doi.org/10.1016/j.ecss.2013.09.018

[38] Verrelst, J., Munoz, J., Alonso, L., Dilegido, J., Rivera, J.P., Camps-Valls, G., Moreno, J. (2018). Machine learning regression algorithms for biophysical parameter retrieval: Opportunities for sentinel-2 and -3 . Remote Sensing of Environment, 118: 127-139. http://dx.doi.org/10.1016/j.rse.2011.11.002

[39] Pal, M., Mather, P.M. (2005). Support vector machines for classification in remote sensing. International Journal of Remote Sensing, 26(5): 1007-1011. http://dx.doi.org/10.1080/01431160512331314083

[40] Wahidin, N., Siregar, V.P., Nababan, B., Jaya, I., Wouthuyzen, S. (2015). Object based image analysis for coral reef benthic habitat mapping with several classification algorithm. Procedia Environmental Sciences, 24: 222-227. http://dx.doi.org/10.1016/j.proenv.2015.03.029

[41] Eastman, J.R., Solorzano, L., Fossen, M.V. (2005). Transition Potential Modeling for Land-Cover Change. Redlands, CA: ESRI Press, 2005.

[42] Congalton, R.G., Green, K. (2009). Assesing the Accuracy of Remotely Sensed Data: Principles and Practices. Second Edition, USA: CRC Press Inc.
[43] Maina, J., Venus, V., Mcclanahan, T.R., Ateweberhan, M. (2008). Modelling susceptibility of coral reefs to environmental stress using remote sensing data and GIS models. Ecological Modelling, 212(3-4): 180-199. http://dx.doi.org/10.1016/j.ecolmodel.2007.10.033

[44] Shidqi, R.A., Pamuji, B., Sulistiantoto, T., Risza, M., Faozi, A.N., Muhammad, A.N., Muharam, M.R., Putri, E.D., Hartini, R., Valentina, B., Fakhri, R.Z., Putra, G.G., Kurniawan, R., Pratomo, A., Syakti, A.D. (2018). Coral health monitoring at Melinjo Island and Sakutu Island: Influence from Jakarta Bay. Regional Studies in Marine Science, $\quad 18$ : http://dx.doi.org/10.1016/j.rsma.2017.02.004

[45] Hedley, J.D., Roelfsema, C., Brando, V., Giardino, C., Kutser, T., Phinn, S.R., Mumby, P.J., Barrilero, O., Laporte, J., Koetz, B. (2018). Coral reef aplications of Sentinel-2: Coverage, characteristics, bathymetry, and benthic mapping with comparison to Landat 8. Remote Sensing Environment, 216: 598-614. http://dx.doi.org/10.1016/j.rse.2018.07.014

[46] Wicaksono, P., Lazuardi, W. (2019). Random forest classification scenarios for benthic habitat mapping. In IGRSM, Japan. http://dx.doi.org/10.1109/IGARSS.2019.8899825

[47] Gong, W.P. (2007). Obtaining water elevation in the lagoon and cross sectionally averaged velocity of the tidal inlet by using one-dimensional equation - a case study in Xincun inlet, Linshui, Hainan, China. Journal Oceanography, 3: 1-5.

[48] Yang, D., Yang, C. (2009). Detection of seagrass distribution changes from 1991 to 2006 in xincun bay, hainan, with satellite remote sensing. Sensors, 9(2): 830844. http://dx.doi.org/10.3390/s90200830

[49] Wang, J., Liu, Y. (2013). Tourism-led land-use changes and their environmental effects in the southern coastal region of Hainan Island, China. Journal of Coastal Research, 29(5): $1118-1125$ http://dx.doi.org/10.2112/JCOASTRES-D-12-00039.1

[50] Hakim, L., Lazuardi, W., Astuty, I.S., Hermayani, A.H.A.R., Novandias, D., Dewi, A.C. (2017). Penilaian kesehatan terumbu karang menggunakan citra Worldview-2 di pulau Pahawang, Lampung, Indonesia. IN Seminar Nasionel Geomatika 2017: Inovasi Teknologi Penyediaan Informasi Geospasial Untuk Pembangunan Berkelanjutan, Bogor. http://dx.doi.org/10.24895/SNG.2017.2-0.405

[51] Jupp, D.L. (1988). Background and extensions to depth of penetration (DOP) mapping in shallow coastal waters. In Proceedings of the Symposium on Remote Sensing of the Coastal Zone, Gold Coast, Queensland.

[52] Stumpf, R.P., Holderied, K., Sinclair, M. (2003). Determination of water depth with high-resolution satellite imagery over variable bottom types. Limnology and Oceanography, 48(1): 547-556. http://dx.doi.org/10.4319/lo.2003.48.1_part_2.0547

[53] Lyzenga, D.R., Malinas, N.P., Tanis, F.J. (2006). Multispectral bathymetry using a simple physically based algorithm. IEEE Transaction On geoscience and Remote Sensing, 44(8): 2251-2259. http://dx.doi.org/10.1109/TGRS.2006.872909

[54] Wicaksono, P. (2015). Perbandingan akurasi metode band tunggal dan band rasio untuk pemetaan batimetri pada laut dangkal optis. In Simposium Nasional Sains Geoinformasi, 
http://dx.doi.org/10.13140/RG.2.1.1340.3286

[55] Hakim, L., Lazuardi, W., Astuty, I.S., Al Hadi, A., Hermayani, R., Novandias, D., Dewi, A.C. (2018). Assessing worldview-2 satellite imagery accuracy for bathymetry mapping in pahawang island, lampung, Indonesia. In Earth and Environmental Science, Semarang. $\quad$ http://dx.doi.org/10.1088/1755- 